\title{
SOME STUDIES IN THE DEVELOPMENT OF RAIL- ROADS IN NORTHEAST IOWA
}

\author{
By Iola B. Quigley
}

\begin{abstract}
${ }^{1}$ The irregular topography of northeast Iowa was responsible for some of the hardships of the pioneers. Difficulties of communication isolated settlements, often many times a year. Wagon roads were poor, narrow and hazardous in the hills, rough and irregular in the lowlands. They were often improved by private subscription, yet travel was difficult everywhere. Stages were frequently pulled out of mudholes in summer, or were delayed by blizzards in winter." Fortunate was the community so situated that the people could use the great natural highways of trade, lakes and rivers.

Steamboat traffic, in the days of settlement, was brisk in summer on the Mississippi. A study of the port of Dubuque from April 8 to April 19, 1859, shows boats for upriver trade varying from two to eleven daily." Annual boat arrivals in St. Paul averaged about one thousand in the early 1860's and most of the boats touched northern Iowa ports twice. ${ }^{4}$

Mail service was very irregular; each day at Dubuque a boat, scheduled to leave at an early hour, was chosen for mail boat, but only one town south of the Minnesota line had more than triweekly service. ${ }^{5}$ Sometimes the Dubuque office had no mail for days; again it was so flooded with matter that it was impossible to get it all out on the next boat. ${ }^{6}$ The McGregor office made up the mail for the interior, weekly, bi-weekly or tri-weekly, dependent upon the distance and amount of mail matter handled at the various stations.

In April, 1857, the Milwaukee \& Mississippi Railroad ran its first train into Prairie du Clien, Wisconsin. ${ }^{7}$ Visitors from Mc-
\end{abstract}

1North Ioua Times, Mar. 16, 1859; July 13, 1864; May 23, 1866; May 8, 1873.

2Powers, History and Reminiscences of Chickasaw County. pp. $191,107,209 \mathrm{ff}^{\prime}$.

3 Dubuque Express and Herald (ditily), Apr. 8-19, 1859.

+Price, History of Clayton County, Vol. I, p. 199

5 Dubuque Express and Herth, Apr. 19, 1857. p. 53.

North Iowa Times, Nov. 7, 1850; Goodspeed, History of Dubuque Comty.

iNorth lowa Times, Apr. 17, 1857. 
Gregor and Clayton City helped their sister city celebrate. Six months before, the editor of the North Iowa Times in its premiere issue, had predicted, "The completion of the railroad to Prairie du Chien will give us all the eastern facilities possessed by any town in the state. The 'neigh' of the Iron Horse cannot yet be heard, but we see the influence of his approach in the increased activity of every man among us.",

Prior to 1857 there were three horse ferries at or near McGregor, but even before the coming of the railroad they proved inadequate. At one time, as early as 1854, 150 wagons waited at Prairie du Chien to be ferried to the Iowa shore. ${ }^{9}$ A fine new steam ferry, the "Alexander McGregor," made its debut in $1856 ;^{10}$ within three years another was added, the "Allamakee,"11 and in the early 1870's a little fleet of chugging boats towed the loaded barges north, south, east and west to and from the busy railway terminus. In the summer of 1860 the Milwaukee \& Mississippi built an elevator at Prairie du Chien. A long, low warehouse with a line of huge doors at the river's edge was added soon. A spur of track ran through the building and cars were loaded in the warehouse directly from the barges. ${ }^{12}$

Immigrants poured into the country. Within a month after the new road was opened, the six passenger coaches arriving daily at Prairie du Chien ${ }^{13}$ were crowded with settlers bound for northeast Iowa or southern Minnesota. Other hordes were coming in by boat or wagon trail. And all this horde meant new business. ${ }^{14}$ In a few months it was announced that the new railroad had all the freight and traffic it could handle until it could increase its capacity. ${ }^{15}$

In the late fall the ferryboats maintained their schedules as long as they could break their way through the ice $;^{16}$ then, until the ice was strong enough to bear traffic, goods piled up at the river ports. When the "natural bridge" spanned the river, the winter barges, horse-drawn, dotted a persistent trail. These sleighs were so constructed as to float if the ice gave way be-

8Ibid., Oct. 10, 1856 (Vol. I, No. 1).

PPrice, History of Clayton County, Vol. I, p. 96.

10North lowa Times, Oct. 10, 1856. 11lbid, Oct. 26, 1859.

12Ibid., Aug. 8, 1860. 13Ibid., Apr. 24, 1857.

14lbid., Aug. 7, 1857; May 30, 1860. 15Ibid., Aug. 7, 1857.

lolbid., Dec. 4, 1861 . 
neath them; if the horses broke through, choke ropes about their necks were drawn taut, to make them float; they could then be dragged out on the solid ice. ${ }^{17}$

On January 26, 1861, 400 teams were in McGregor. ${ }^{18}$ All sorts of conveyances came laden with produce, from "the sleek team of the wealthy German, and the small ' $g$ 'lang' ponies of the fast Yankee, to the slow bovines of the honest Norwegian."19 Three million bushels of wheat were shipped through McGregor during the year ending $J u l y ~ 1,1861,{ }^{20}$ although a considerable part of this went by boat.

But steel ribbons were slowly stretching westward from river towns farther south, and McGregor could not lag behind. As soon as the railroad was assured for Prairie du Chien, business men on the Iowa side began to plan connecting lines. The first number of the North Iozva Times, October 10, 1856, named two projected roads, "The Northern Iowa \& Minnesota Railroad" and the "McGregor, St. Peter's \& Missouri River Railroad." Discussion was rife as to the most feasible route. McGregor business men were hopeful that one of the narrow ravines leading from the town might be the chosen way.

Allamakee County advocated the Yellow River valley, where ran the old military road connecting Fort Atkinson in Iowa with Fort Crawford at Prairie du Chien. There was also the valley of the "Bloody Run," the Giard River of trapper days."

And many were the proposed lines for survey inland. Every little town dreamed of future wealth and power when it should "get the railroad."

The first company to incorporate was the McGregor, St. Peter's \& Missouri River Railroad Company, June 2, 1856."2 The surveys were begun in July, and the Bloody Run valley chosen as the only practical route leading up to the table-lands. A tenta tive line westward was planned by way of Clermont, West Union, Fredericksburg, Bradford (Chickasaw County), St. Charles, Mason City, "with a population of at least five hundred," and

1iInterview with Mr. F. H. Luthe, Des Moines, Iowa.

18 North Iowa Times, Jan, 30, 1861. 10Ibid., Dec. 25, 1861.

20Ibid., Nov. 13, 1861 .

21lbid., Feb. 6, 1857 (The survey was completed July 2, 1856).

22Ibid., Feb. 6, 1857. 
Clear Lake City. A second company was formed to build the "Northwestern Railway" to connect with the McGregor, St. Peter's \& Missouri River road, to run by way of Postville, Frankville, Decorah; Elliota, and St. Peters, in Minnesota. ${ }^{23}$ A third company, "The Dubuque \& Turkey Valley Railroad Company," was incorporated to run a line from Dubuque to the mouth of the Turkey River, thence up that valley to Minnesota. ${ }^{24}$

The directorate elected for the McGregor, St. Peters \& Missouri River Railroad, in June and July, 1857, represented Clayton, Fayette, Chickasaw, Floyd and Kossuth counties; Wisconsin capitalists were interested in this extension of their Milwaukee and Mississippi road, and we find a director from Waukeshaw, and another from Milwaukee. Eastern capital is not unaware of the new venture for J. C. Wright, New York, is also on the board..$^{25}$

And how were such ventures to be financed? The estimated cost, made somewhat later, for the McGregor, St. Peter's \& Missouri River, for roadbed and equipment, was set at $\$ 2,112,990$ for the first and most difficult fifty miles. ${ }^{2 \mathfrak{j}}$ And yet, at first, it was hoped that local or at least Western capital could be found to finance it largely by purchase of stock by business men and farmers. ${ }^{27}$ Enthusiastic meetings were held in the towns along the projected route. ${ }^{28}$ The farmer was urged to give even to the full value of his land. "It will be the means of quadrupling his real estate if he wishes to sell, and in the same proportion, increase his facilities to cultivate his land, dispose of his produce and to procure the comforts and luxuries of life if he wishes to keep it." Land was deeded by private owners to the railroad. Such a donor was David Edwards, New Hampton; he gave 240 acres, nearly one half of his holdings, "and," says Larrabee, "the donations were all absorbed without any perceptible advance in building the road."

Sometimes the county or township or city took stock in the company, giving bonds in payment. This had been commonly

23lbid, Dec. 5, 1856; July 24, 1857. 24Ibid., Feb. 27, 1857.

25Ibid, June 12, 18.57 ; July 10, 1857 . 26Ibid., Mar. 31, 1858.

2 I Ibid., Mar. 6, 1857 ; Feb. 3 , 1858.

28Ibid., Mar. 6, 1857; Mar. 13, 1857; Mar. 20, 1857 ; Dec. 1, 1858.

29larrabee, The Railroad Question, p. 8; also Powers, History and Remimiscences of Chickasaw County, pp. 192, 193. 
resorted to in other states, had, indeed, been worn rather threadbare before efforts were made to finance Iowa's first railroad (1853). A Supreme Court decision had upheld the constitutional right of a county to aid in building a railroad within its limits in the case of Dubuque County, which voted $\$ 200,000$ to aid the Dubuque \& Pacific Railroad Company..$^{30}$ It was argued that the constitutional restriction of state debt to $\$ 100,000$ offered no restriction in this instance because: (1) The county was not the state. (2) A railroad is as necessary as any other road. Judge Kinney filed a dissenting opinion because: (1) It interferes with the private rights of citizens. (2) The legislature of $1850 \mathrm{had}$ rejected a bill for county subscription for public improvement on the ground that it was unconstitutional. (3) A railroad is not a road as per approved usage. He regarded the wild taxation for. railroads by counties as alarming. Governor Grimes also warned against this method of financing railroads. In his message of December, 1856, he noted that the aggregate debts of the counties were over seven millions, and that some projects were bound to result disastrously. "Municipal corporations are designed for local and limited purposes and it is a perversion of their organization when they are embarked in internal improvement beyond their jurisdiction." 31 He argued that it was not legal for the voters of one portion of the county to fix a tax on persons of remote parts except for county purposes. He advised legislative control of the problem.

But the need was great and the future was bright; a legislative act, approved January 21, 1857, enabled Clayton County to issue bonds "to aid in the construction" of the Dubuque \& Turkey Valley and the McGregor, St. Peter's \& Missouri River Railroad. ${ }^{3: 2}$ The county judge advertised a special election and bonds to the value of $\$ 100,000$ bearing ten per cent interest were voted by a majority of $693 .^{33}$ Chickasaw County had already voted $\$ 100,000$ worth of bonds for the McGregor, St. Peter's \& Missouri River Railroad Co. and later voted $\$ 100,000$ more for the Chicago, Iowa \& Nebraska Railroad, Cedar Valley branch, both

30Greene, 4 Iowi Reports, pp. 2, 3.

is Shambiugh, Messages and Proclamations of the Govemors of lowa, Vol. II, p. 38 .

32 Laws of Iowa, 1856, Chap. 186. 33North lowa Times, Mar. 13, 1857. 
bearing ten per cent interest. ${ }^{34}$ In order to attract western capital the McGregor, St. Peter's \& Missouri River Railroad Co. determined to invest one half of its funds in public lands to be sold for the benefit of the stockholders. ${ }^{35}$

A campaign for a land grant to aid in building this road was begun late in $1857 .^{30}$ But that plan had also been overworked and Congress was much slower to grant such aid than it had been a decade before. It is doubtful if the best of help could have protected these early Iowa projects from disaster. The railroad panic of 1857 made it impossible to get Eastern capital, and more slowly, but just as surely, the blight settled upon the West. $^{37}$ The following year came the most complete crop failure that Iowa had ever experienced. ${ }^{38}$ Subscriptions of stock could not be paid. It was vain to urge the farmers to pay for their stock in wheat, "for which," wrote Editor Richardson, "no market exists . . . and yet will pay for that which will assure a future market." Most persistent was his warning to "avoid Eastern encumbrances" ; 39 the results of such a course seemed only too obvious, and yet what chance had the meager West to finance a railroad substantially?

In May, 1858, the McGregor, St. Peter's \& Missouri River Railroad Company were forced to discharge their men and suspend operations. ${ }^{40}$ Nine miles of road, as "crooked as a ram's horn," crossing Bloody Run twenty-seven times, had been graded. ${ }^{4 l}$ Interest was not dead; it was hoped that work might begin again soon, and in November a meeting was held in West Union that new life might be instilled in the project. Stock was subscribed conditionally, to be paid for only in case the road ran through Clermont and West Union. The delegates also resolved to ask state aid for the enterprise. At this meeting the directors

\footnotetext{
34Powers, Histony and Reminiscences of Chickasaw County, p. 62; North Iowa Times, Oct. 10,1856 .

35 North lowa Times, July 17, 1857; July 24, 1857.

36Ibid., Dec. 23, 1857 (copied from Dubuque Tribune).

37Ibid., Aug. 14, 1857; Feb. 3, 1858 .

$38 \mathrm{Ibid.,}$ Feb. 3, 1858 ; also Fleming to Houghton, Iowa Archives, G II, 5 (Letter book), p. 37; also Iowa Historical and Comparative Census, 1836-80, p. $\times x i$.

30 North Iowa Times, Feb. 3, 1858.

40Price, History of Clayton County, Vol. I, p. 123; also North Iowa Times, June 26, 1850 .

41 North Iowa Times, Nov. 28, 1866 (Historical sketch of the railroad).
} 
reported $\$ 400,000$ in subscriptions, including $\$ 55,000$ worth of land. ${ }^{42}$

Meanwhile persistent opposition was maintained against county and township aid. In 1859 the Supreme Court of Iowa decided: "The counties of this state have no power to borrow money or subscribe stock to aid in the construction of railroads, and the issuing of bonds by the counties or the transfer of them by the corporations to whom they are issued may be restrained by injunction." ${ }^{\text {3 }}$ This startling reversal increased the difficulties of all roads building in Iowa.

It was rumored that the Milwaukee $\&$ Mississippi Road would purchase a controlling interest in the M., St. P. \& Mo. R. R. R. if the stockholders would agree to a resurvey and a new location; but President "Jack" Thompson refused to consider any plan that did not assure his home town, Clermont, a railroad. ${ }^{44}$

In October, 1859, one, William B. McNamara, levied upon the M., St. P. \& Mo. R. R. R. to satisfy a judgment of $\$ 1,560.50$. Mr. Larrabee says that all of the old stock was wiped out by this process and the road went into the hands of new owners. ${ }^{45}$ Plans for state aid were discouraged in Governor Lowe's biennial message to the legislature, January 9, 1860. He declared that the majority of the people were against it and that the plans for railroad building in Iowa would probably fail; capital was unwilling to invest, and in such projects the masses never help. But he pointed out, too, the significant fact that the emigrant trains were diverted to other states with better railway facilities. Governor Lowe also cited the provisions of the act of Congress whereby the state of Iowa was granted land to aid in building four Iowa railroads (1856). The stipulation that seventy-five miles must be built by 1859 had not been complied with in any instance; he advised the legislature to resume the lands, make a new grant, and to stipulate that a majority of the boards of directors reside and keep office in the state. ${ }^{46}$ One of

42 Ibid., Dec. 1, 1858.

43Withrow, 10 Iowa Reports, p. 166, Stokes vs. Scott Co.

44 North Iowa Times, Aug. 31, 1859.

45Ibid, Oct. 19, 1859; Apr. 11, 1860. Realvertised after litigation, North Iowa Times, Aug. 8, 1860. Also, Larrabee, The Railroad Question, p. 32.4.

46Shambaugh, op. cit., Vol. II, p. 174. "Although this description of improvements are peculiarly adapted to the wants and interests of the masses, they never yet have been prevailed upon to do much for'. enterprises of this kind." 
the companies that had forfeited its grant was the Iowa Central Air Line, a road planned to run westward on or near the fortysecond parallel of latitude. ${ }^{47}$ Other roads sought eagerly for the grant. The McGregor road had felt themselves aggrieved because they had been excluded from the grant of 1856. Now interest began to renew itself. They could not compete for the forty-second parallel grant, but they could try for a new one. The times seemed propitious. The Cedar Valley Railroad, projected northward to the state line, which, for a time, seemed sure of success, was delayed. ${ }^{48}$ A new company was organized to take over the franchises of the McGregor and St. Peter's road, the "Northern Iowa Railroad Company," and a new survey was made (1861). ${ }^{49}$ The new company planned to build the road to Clermont, and stock the western line, to be built by the old company, the McGregor, St. Peter's \& Missouri River. Subscriptions came in briskly from county and individual. Counties were urged to turn over their swamp land grants. We find Howard County planning thus to help finance the northern branch through $\mathrm{New}$ Oregon, ${ }^{50}$ besides subscriptions of more than $\$ 100,000$ from Howard County residents. Thus the dreams of the old Northwestern road seemed nearer realization than the road projected westward. $^{51}$ The new company, the Northern Iowa, was pronounced amply able to complete the project, ${ }^{52}$ but we soon find them involved in further difficulties. Work had progressed actively during early summer. The contractors promised that twenty miles would be ready for the iron by October 1, and that a locomotive would be in Monona by January 1, 1862. ${ }^{53}$ But in September a subcontractor fled with the funds which should have been paid to his men; after a few days of idleness a riotous mob attempted to collect what was due them. At North McGregor and Monona were company stores; the men in charge made no attempt to oppose the raiders, who carried away groceries, dry goods, bedding, etc. Then the mob started for McGregor, where they sus-

47 North Iowa Times, Feb. 1, 1860; Feb. 8, 1860; Feb. 15, 1800.

48Ibid., June 6, 1860 ; Nov. 14,1860 .

49lbid., Dec. 19, 1860 ; Nov. 28, 1860 (a historical sketch) Larrabee calls this the "McGregor Western." This is undoubtedly an error, as notice of the incorporation of that company was filed in 1863 . Larrabee, op. cit., p. 325 .

50North lowa Times, Mar. 13,1861 . This grant was not voted until 1865, see 1bid., Nov. 29, 1865.

51Ibid., Nov. 14, 1860. 52Ibid., Dec. 19, 1860.

53Ibid., June 26, 1861; July 27, 1861 . 
pected President Thompson was to be found. ${ }^{54}$ The offices of the railroad were above the $O$. C. Lee private bank, located on the south side of the street in the block nearest the Mississippi River. Mr. Thompson was there, trying to negotiate a loan to tide over the emergency. There were wild demands for a lynching. The citizens of little McGregor were thoroughly alarmed and a messenger was sent post haste to beg the help of Father Nolan, priest in charge of St. Mary's church. That gentleman was one of the most forceful characters in the early history of the community. He was a handsome man, more than six feet tall, of sterling character and great firmness. The messenger found him at the bedside of a sick parishioner, a few miles from town. Seizing an oxgoad he mounted his waiting horse and rode pellmell to McGregor. Down the street, through the mob he forced his way, lashing right and left with the oxwhip. The wild Irish mob was thoroughly cowed, and ready to listen to reason. ${ }^{55} \mathrm{Mr}$. 'Thompson appeared on the balcony above the bank, a promise of immediate payment of wages in arrears quieted the leaders, the banks of McGregor furnished the money on Mr. Thompson's personal note, and the rioters disbanded. ${ }^{56}$ One or two of the leaders, who feared their indignation had carried them beyond the limits of the law, enlisted for the Civil War, rightly thinking that thereby they would escape arraignment. ${ }^{57}$

But work was not resumed. Finances were at a low ebb. President Thompson was not the only promoter facing financial ruin. Hopes of a railroad westward sank low, indeed. The editor of the Freeborn County (Minn.) Standard wrote: "That man must be verdant indeed who imagines that a railroad will ever be built up Jack Thompson's ram's horn location and partially graded track up the circuitous military ridge. Successful railroad companies don't generally crook their roads around houses, gardens and stables, and wind along ridges losing five miles in advancing forty. We can but look upon the enterprise as a contemplated

54Ibid., Sept. 11, 1861 .

55The North lowa. Times passes over this episode lightly, but it was told to the writer in almost identical fashion by Mrs. lmogene Wadsworth Davis, Mrs. H. H. Clark and Mr. George Pearsall. George Pearsall, then a small boy of nine or ten years, was hanging about the outskirts of the crowd when Father Nolan appeared.-I, B. Q.

56North lowa Times, Sept. 11, 1801.

57Interviews with Mrs. Davis, Mr. Fred Williams, son of Judge Elias Williams, Mr. Alonzo Boyle, and Mr. Robert Quigley. 
swindle and humbug." 58 Moreover the Civil War had begun; money was "tight" and the project was forced to lie dormant for a more favorable season.

In 1862 a Supreme Court decision denied the legislature of Iowa the power to authorize counties to become stockholders in railroad companies. This was an added blow to those concerned in the northeast Iowa projects. ${ }^{59}$

January 19, 1863, the McGregor Western Company was organized..$^{80}$ A subsidiary company, "The Iowa Railway Construction Company," was also formed. "By some legal process not necessary to state, the franchise of the road reverted to Judge Brown, ${ }^{\prime, 61}$ who sold it to the new corporation. The Milwaukee \& Prairie du Chien company was not complacent at the turn of affairs. They were of a mind to control any road built westward from McGregor when the time was ripe for building. When the Northern Iowa company was organized a rival company, "The Prairie du Chien \& Austin Railroad Company," had been incorporated, its board of directors composed largely of stockholders of the Milwaukee \& Prairie due Chien Railway. They proposed to begin at Paint Creek, some nine miles north of McGregor, and build to southern Minnesota by way of Waukon, Frankville, Calmar and Howard Center. ${ }^{62}$ But when work on the Northern Iowa ceased the Paint Creek project languished, only to spring up again to oppose the McGregor Western. A new company bought the franchise. ${ }^{63}$ They also secured franchises in Minnesota and gave every evidence of active opposition. ${ }^{64}$ But work on the McGregor Western was pushed actively and in June the Paint Creek project was reported as abandoned. ${ }^{65}$

Meanwhile another formidable rival appeared, the Minnesota \& Cedar Valley Railroad, with its northern terminus at Otranto, crossing the prospected line of the McGregor Western at Bradford in Chickasaw County. It was planned to extend through

58 North Iowa Times, Jan. 15, 1862.

59Withrow, 13 Iowa Reports, p. 388, State of lowa ex rel B. \& Mo. R. R. R. vs. Wapello County.

on North Iowa Times, Jan. 28, 1803.

B1Larrabee, op. cit., p. 325. Judge Jedediah Brown was the first secretary of the M.. St. P. \& Mo. R R. R.

62 North Iowa Times, May 29, 1861. 63Ibid., Mar. 11, 1863.

64lbid., Apr. 22, 1863 ; May 6, 1863 . 65Ibid., June 10, 1863. 
Blackhawk, Bremer, Chickasaw, Floyd and Mitchell counties. ${ }^{63}$ "County subscriptions, whether worth anything or not, have been voted without limit," wrote a correspondent from that section.

Finally through the efforts of William B. Allison and others, a land grant was secured for the McGregor road. ${ }^{67}$ It stipulated that the road must be built on or near the forty-third parallel. Meanwhile the road was creeping slowly westward. From Postville one line was planned to extend northwest to the state line; the other, westward, was to be built through Clermont, West Union, etc. In October the first engine arrived. By the middle of June, 1864, trains reached Postville; by April, 1865, trains were running to Ossian; the railroad was no longer a dream. ${ }^{68}$ Then the Milwaukee \& Prairie du Chien leased the new road for ninety-nine years. The depots at Prairie du Chien were moved to a point opposite North McGregor, a new town, a mile or more north of McGregor which had sprung into existence when the Bloody Run survey was made. ${ }^{69}$ Two ferry boats, the Allamakee and the Jennie Brown, towed great barges, fitted with tracks, for transportation of the loaded freight cars across the Mississippi. These boats and barges were owned by John Lawler, onetime station agent at Prairie du Chien, but rapidly becoming an important factor in railroad history of Northern Iowa. ${ }^{70}$

The northern branch was ready for the iron by the fall of 1865 ; Cresco, in Howard County, was to be the terminus, for a time, at least, so Howard County forthwhile voted her swamp lands to help finance the railroad. ${ }^{71}$

But the companies were not complying with the terms of the land grant. The road was extended northward instead of along the forty-third parallel. Its eastern terminus was at North McGregor, not at McGregor, as the terms of the grant required."2 Governor Stone was ready to certify the lands due for the first fifty miles completed; but the storm of protest was so great that

G0Ibia., Nov. 18, 1863 .

67Congressional Globe, 1863-64, pp. 281, 1314, 1559, 1791.

68 North lowa Times, Oct. 14, 1863; Mar. 2, 1864; May 18, 1864; June 15, 1864. 69Ibid, Jan. 29, 1862 ; Feb. 24, 1864; May 4, 1864 .

70Interview with H. Martner of Prairie du Chien, an engineer on the Milwaukee \& Prairie dı Clicen Railroad.

71 North lowa Times, Mar. 13, 1866; Nov. 14, 1866. For legalization of this grant, see Laws of Iowa, 1868, Cl. 37. See also North Iowa Times, Oct. 30, 1867 . Rond is built to state line.

72Ibid., Feb. 7,1866 . 
the legislature failed to approve the governor's action, and Secretary of the Interior Harlan set in motion an investigation. So again the McGregor and Missouri company was reorganized under the name, the "Calmar \& Missouri River Railway," to build the western extension. Once more rivals appeared. ${ }^{73}$ Two new companies, the "Mississippi \& Sioux City" with a road projected by way of Yellow River, and the "McGregor \& Missouri Land Grant Railroad Company," with a prospective route up Paint Creek. Both began to work for the land grant. ${ }^{74}$ Out of the melee the McGregor \& Sioux City emerged as the recognized heir of the McGregor Western, and favored claimant.

Finally in 1868 the Prairie du Chien road was bought by the Milwaukee \& St. Paul. This insured adequate financing of the northern Iowa road for the first time. ${ }^{75}$ But it also meant control by New York capitalists, control so powerful and so adequate that rival claims of a dozen little towns for a place on the railroad map could be safely disregarded. But still the lands were not certified. A new company; the "Forty-third Parallel" road, appears, with important McGregor men among the stockholders. ${ }^{75}$ It is somewhat of a mystery; its motives are questioned; public opinion scouts the idea that they mean to build. ${ }^{77}$ The promoters claim that its object is twofold, one to force the McGregor and Sioux City to comply with the terms of the grant, and the other "to bring the weight of the grant to bear in abating the tariff discriminations on produce in transit from interior points and river towns." 78 'They petitioned the state legislature to award them the grant. Great pressure was brought, especially in McGregor, where the citizens waged a spirited fight. ${ }^{79}$ The members from Clayton County favored the McGregor and Sioux City. McGregor citizens maintained a lobby at Des Moines, ${ }^{80}$ and finally, when the legislature awarded the grant to that railroad company, there were stipulations as to tariff regulation, etc., very obnoxious to the New York stockholders. ${ }^{81}$ They published

73Ibid., Mar. 28, 1866 .

74Ibid., Aug. 29, 1866; Price, History of Clayton County, Iowa, Vol. I, p. 202.

75 North lowa Times, Jan. 8, 1868 . 76lbid., Mar. 11, 1808.

77Ibid., Mar. 11, 1868 . 78Ibid., Mar. 18, 1868.

79lbid,, Mar, 25, $1808 . \quad$ solbid., Apr. 1, 1808; May 28, 1868.

81'This was the famous "Doud Amendment" adopted by Twelfth G. A.. 1868 , when they regranted M. \& M. lands to the C., R. I. \& P.; it was added to all subsequent grants. 
a protest, accepting the terms of the grant "with reservations"; but the Forty-third Parallel Company announced their readiness to accept the grant with all stipulations in accordance with the terms of the bill making them beneficiaries in case the Sioux City road rejected them. ${ }^{82}$ A lively controversy ensued between Governor Merrill of Iowa, and Russell Sage of New York, president of the company. ${ }^{83}$ The latter protested against the unfair restrictions. He declared the good faith of the compiny.

The new company was very active. A thousand men were at work on the western extension, ${ }^{84}$ and plans were made to build the tracks down to McGregor, to comply with the land grant act. In some instances western counties donated their swamp lands. ${ }^{8 \pi}$ In spite of the fact that the Supreme Court had again spoken, ${ }^{86}$ and that taxation of cities and towns for aid of railroads was declared unconstitutional, the General Assembly of that winter, the "Railroad Legislature," passed an act authorizing cities, townships and towns to levy a tax not exceeding five per cent for aid in building a road within their boundaries. The company must first show that twice the amount asked for had been spent in that locality before the money was collectable. ${ }^{87}$ The constitutionality of this act was passed upon by the Iowa Supreme Court and was upheld..$^{88}$

An honest effort was made to extend the road to its western terminus, then set at Yankton, South Dakota, by way of Sioux City. ${ }^{89}$ But in 1872 the company was forced to ask for an extension of time, as the road had not yet reached Spencer. ${ }^{00}$ There was much opposition to this, especially at McGregor, whose citizens were smarting under the failure of the company to extend its line to the limits of their city. Finally the road was extended , to Algona, but the panic of 1873 made progress impossible. Not until 1875 was the work resumed. ${ }^{91}$ In 1878 the road was completed to Sheldon, the terminus stipulated in the land grant act of $1864 . .^{92}$

82 Ibid., June 17, 1868.

83Ibid., July 12, 1868. 84Ibid. Sept. 16, 1868.

85Ibid., May 18, 1870. Cerro Gordo, Allamakee, Chickasaw, Fayette. Also see Laws of lowa, 1870 , Ch. 10.

86Stiles, 27 Iowa Reports, p. 29. 87 North lowa Times, Oct. 12, 1870.

88 Stiles, 30 lowa Reports, p. 9. 89 North Iout Times, Sept. 22, 1869.

golbid., Feb. 6, 1873 .

nilbid., May 1, 1873. The land was three times resumed and regranted. The road was completed to Sheldon in 1878 . Larrabee, op, cit., p. 327.

92Sixty-fourth Cong., 1 Ses., Doc. 404, Iowa Railway Land Grants, p. 41. 
Copyright of Annals of Iowa is the property of State of Iowa, by \& through the State Historical Society of Iowa and its content may not be copied or emailed to multiple sites or posted to a listserv without the copyright holder's express written permission. However, users may print, download, or email articles for individual use. 